\title{
Characterization of Road Traffic Emissions in a Densely Populated Residential Area of Kuwait
}

\author{
Karim N. Jallad ${ }^{1} \&$ Cyntia Espada-Jallad ${ }^{2}$ \\ ${ }^{1}$ College of Arts and Sciences, American University of Kuwait, Kuwait \\ ${ }^{2}$ Midwest Research Institute, Kansas, USA \\ Correspondence: Karim N. Jallad, College of Arts and Sciences, American University of Kuwait, P. O. Box 3323, \\ Safat 13034, Kuwait. Tel: 965-2224-8399-423. E-mail: kjallad@auk.edu.kw
}

Received: February 1, 2012 Accepted: February 22, 2012 Online Published: June 1, 2012

doi:10.5539/enrr.v2n2p2 URL: http://dx.doi.org/10.5539/enrr.v2n2p2

\begin{abstract}
Analysis of road traffic emissions in the Salmiyah residential area of Kuwait was conducted over a period of 12 months, from March 2008 to February 2009. Salmiyah is a densely populated area, mainly by expatriates. Apartment buildings are the dominant type of dwellings available in Salmiyah. Major highways surround this residential area where heavy traffic congestion occurs during rush hours. The objectives of this work were: to monitor ambient tropospheric levels of carbon monoxide $(\mathrm{CO})$, nitrogen dioxide $\left(\mathrm{NO}_{2}\right)$, sulfur dioxide $\left(\mathrm{SO}_{2}\right)$, non-methane hydrocarbons (NMHC), and ozone $\left(\mathrm{O}_{3}\right)$, to understand their diurnal behaviors, and to study their seasonal trends. The results of this study indicated that (i) $\mathrm{CO}, \mathrm{NO}_{2}, \mathrm{SO}_{2}, \mathrm{NMHC}$ and $\mathrm{O}_{3}$ exceeded the ambient air quality standards during specific times of the year; (ii) the diurnal patterns for $\mathrm{CO}, \mathrm{SO}_{2}, \mathrm{NO}_{2}$, and $\mathrm{NMHC}$ showed three peaks which were directly dependent on high traffic density, while only two daily maxima were observed in the case of $\mathrm{O}_{3}$; (iii) $\mathrm{O}_{3}$ compared to the other gaseous pollutants exhibited a completely opposite monthly mean distribution since the highest concentration levels were detected during the summer season (July and August).
\end{abstract}

Keywords: traffic emissions, air pollution, respiratory diseases, carbon monoxide, ozone

\section{Introduction}

Due to Kuwait's prosperity and fast progression as a developing country, the number of vehicles has been growing at a high rate. In 2006 there were approximately 1 million registered vehicles in Kuwait, and the estimated annual increase in registered vehicles is between 6 to $9 \%$ since then (Al-Traiji, 2007). As a result, in Kuwait, emissions from motor vehicle exhausts contribute significantly to the urban pollution load. Since these toxic air pollutants are emitted in close proximity of residential areas, they have the potential to subject the residents to health risks (Watson, Bates, \& Kennedy, 1988). In recent years, studies in the United States, Europe, and Asia have reported that exposure to air pollution is associated with numerous effects on human health. These effects include, but not limited to, respiratory, cardiac, and neurological impairments. The health effects vary greatly from person to person; nevertheless, high risk groups such as the elderly, infants, pregnant women, and sufferers from chronic and lung diseases are more susceptible to air pollution (Westerdahl, Wang, Pan, \& Zhang, 2009). In addition, studies reported a clear association between traffic related pollutants and respiratory diseases (Hoek, Brunekreef, Goldbohm, Fischer, \& Van den Brandt, 2002; Maheswaran \& Elliot, 2003).

Air pollution is classified into two types according to the source of emission. Primary pollutants are emitted from their sources directly to the atmosphere and secondary pollutants are the products of chemical reactions taking place between the primary pollutants. Carbon monoxide $(\mathrm{CO})$, nitrogen dioxide $\left(\mathrm{NO}_{2}\right)$, sulfur dioxide $\left(\mathrm{SO}_{2}\right)$, and non-methane hydrocarbons (NMHC) are examples of primary pollutants while ozone $\left(\mathrm{O}_{3}\right)$ is a secondary pollutant (Eubanks, Middlecamp, Heltzel, \& Keller, 2009). In light of these facts, motor vehicles' emissions contribute significantly to high ambient air levels of primary pollutants and are indirectly responsible for the formation of ground level $\mathrm{O}_{3}$, a photochemical oxidant, by providing its precursors $\left(\mathrm{NMHC}^{\mathrm{and}} \mathrm{NO}_{2}\right)$.

The study presented in this paper aimed at evaluating the $\mathrm{CO}, \mathrm{NO}_{2}, \mathrm{SO}_{2}, \mathrm{NMHC}$, and $\mathrm{O}_{3}$ pollution levels in the Salmiyah residential area of Kuwait over a period of 12 months, from March 2008 to February 2009. The objectives of this work were: to monitor ambient tropospheric levels of these criteria air pollutants for comparison both to the United States Environmental Protection Agency National Ambient Air Quality Standards 
(USEPA NAAQS) and to the 2007 annual average values reported from different sites in the United States, to assess their health effects, to understand their diurnal behaviors, and to study their seasonal trends. The latest study addressing the air quality in Kuwait was published back in 2004 (Abdul-Wahab \& Bouhamra, 2004) and was based on data collected during 1997. The 1997 monitoring site has a different architectural design from the current site since single family houses (no residential apartment buildings) are the dominant type of dwellings (mainly Kuwaiti residents) and fewer highways (less traffic congestion thus less emissions) surround the area. The authors called in their concluding remarks for governmental control measures regarding traffic planning especially through residential areas since traffic was a major contributor to ambient air levels of $\mathrm{CO}, \mathrm{NO}_{2}, \mathrm{SO}_{2}$, and NMHC. Although the previous study was conducted in a different residential area (Figure 1a), it is worth mentioning that all the pollutants' levels reported in this paper were significantly higher than those collected back in 1997.

\section{Materials and Methods}

\subsection{Instrumentation}

The measurement of the criteria air pollutant gases was done using a monitor fitted with sensor heads (Aeroqual Outdoor Ambient Air Quality Monitor; Auckland, New Zealand) based on Gas Sensitive Semiconductor (GSS) technology. It is a combination of smart measurement techniques and mixed metal oxide semiconductor sensors that exhibit an electrical resistance change in the presence of a target gas. This resistance change is caused by a loss or a gain of surface electrons as a result of adsorbed oxygen reacting with the target gas. If the oxide is an n-type, there is either a donation (reducing gas) or subtraction (oxidizing gas) of electrons from the conduction band. The result is that n-type oxides increase their resistance when oxidizing gases such as $\mathrm{CO}, \mathrm{SO}_{2}, \mathrm{NO}_{2}$ and $\mathrm{O}_{3}$ are present while reducing gases such as NMHC lead to a reduction in resistance. The converse is true for p-type oxides where electron exchange due to gas interaction leads either to a rise (oxidizing gas) or a reduction (reducing gas) in electron holes in the valence band. This then translates into corresponding changes in electrical resistance.

Quantitative response from the sensor is possible as the magnitude of change in electrical resistance is a direct measure of the concentration of the target gas present. The operating parameters for the sensors are as follows; $\mathrm{CO}$ (detection range $0-100 \mathrm{ppm}$; resolution $0.05 \mathrm{ppm}$; temperature $0-40{ }^{\circ} \mathrm{C}$; relative humidity 5 to $95 \%$ ), $\mathrm{SO}_{2}$ (detection range $0-10 \mathrm{ppm}$; resolution $0.2 \mathrm{ppm}$; temperature $-20-40{ }^{\circ} \mathrm{C}$; relative humidity 5 to $95 \%$ ), $\mathrm{NO}_{2}$ (detection range $0-200 \mathrm{ppb}$; resolution $1 \mathrm{ppb}$; temperature $0-40{ }^{\circ} \mathrm{C}$; relative humidity 30 to $70 \%$ ) $\mathrm{O}_{3}$ (detection range $0-500 \mathrm{ppb}$; resolution $1 \mathrm{ppb}$; temperature $-5-50{ }^{\circ} \mathrm{C}$; relative humidity $5-95 \%$ ), and $\mathrm{NMHC}$ (detection range $0-25 \mathrm{ppm}$; resolution $0.1 \mathrm{ppm}$; temperature -20 to $50{ }^{\circ} \mathrm{C}$; relative humidity $5-95 \%$ ). The instrument was also capable of collecting meteorological data such as temperature, humidity, wind speed and direction. The sensor heads were controlled by an intelligent data logger; automatic zero and span calibrations were performed using a calibration gas every 23 hours.

\subsection{Area Description}

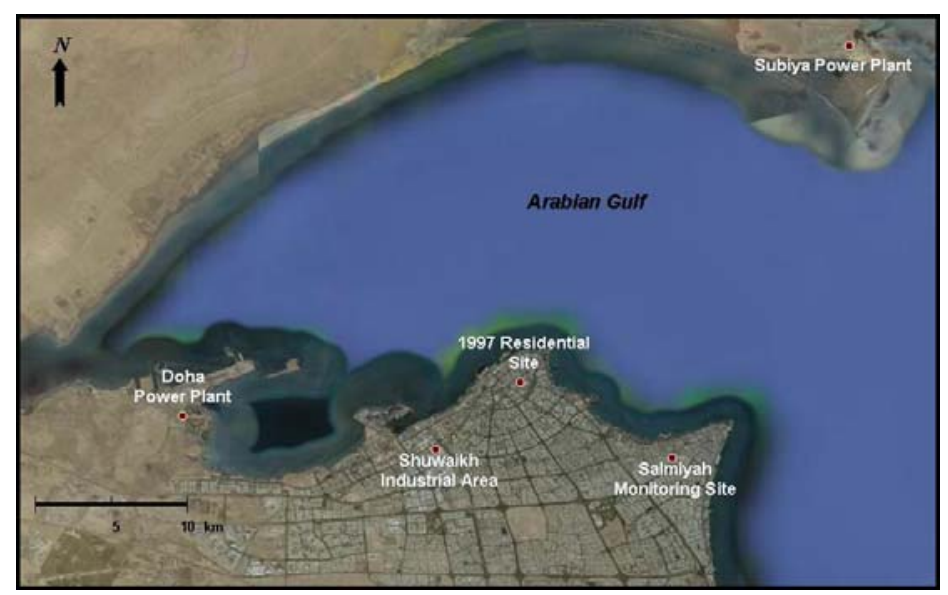

Figure 1(a). Location of the Salmiyah residential site in relation of other sites of interest 
$\mathrm{CO}, \mathrm{SO}_{2}, \mathrm{NO}_{2}, \mathrm{NMHC}$, and $\mathrm{O}_{3}$ were monitored daily for a period of one year extending from March 2008 till February 2009 (weather permitting; monitoring was cancelled in case of rain, high wind, and sand storms) at an altitude of 25 meters and a geographical location (black square) illustrated in Figure. 1b. Salmiyah is a densely populated area, mainly by expatriates. Apartment buildings are the dominant type of dwellings available in Salmiyah (no condos or single family houses). The location is surrounded by major highways that experience traffic congestion at peak hours of the day.

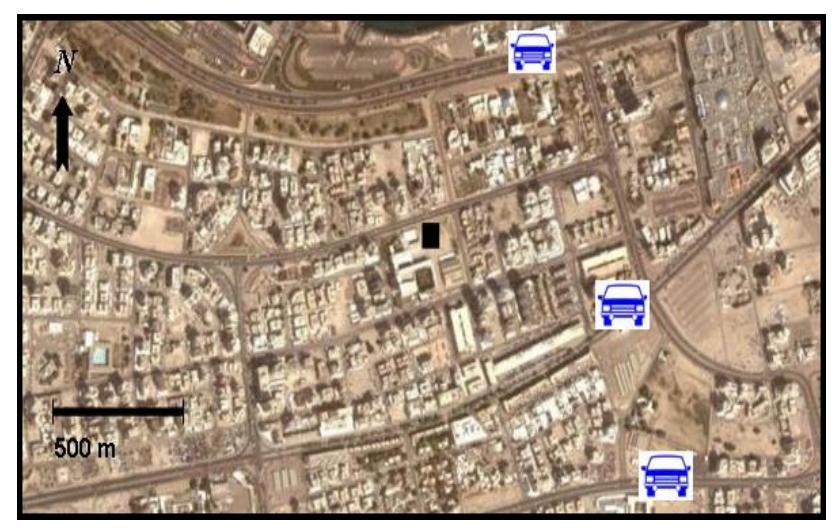

Figure 1(b). Location of monitoring site in the Salmiyah residential area surrounded by three major highways

\section{Results and Discussion}

\subsection{Tropospheric Concentration Levels}

The monthly means for $\mathrm{CO}, \mathrm{NO}_{2}, \mathrm{SO}_{2}, \mathrm{NMHC}$, and $\mathrm{O}_{3}$ concentrations along with the maximum and minimum recorded readings during that month are listed in Tables 1 to 5 , respectively. In case of both $\mathrm{CO}$ and $\mathrm{O}_{3}$, the monthly concentration mean representing the peak hour observed is also listed (Table 1 and Table 5). The annual means along with both the maximum and minimum annual recorded values for $\mathrm{CO}, \mathrm{NO}_{2}, \mathrm{SO}_{2}, \mathrm{NMHC}$, and $\mathrm{O}_{3}$ are listed in Table 6. In addition, the US EPA NAAQS (Code of Federal Regulations, 2005) together with the 2007 annual average values reported from different sites in the United States are also shown (United States Environmental Protection Agency, 2008).

Table 1. Monthly means for concentrations, peak hour concentrations, and inhaled molecules of CO along with maximum an minimum readings

\begin{tabular}{lllllll}
\hline Month & $\begin{array}{l}\text { Maximum } \\
8 \mathrm{hr} \\
\text { Average } \\
(\mathrm{ppm})\end{array}$ & $\begin{array}{l}\text { Inhaled } \\
\text { Molecules } \\
\text { per } 8 \mathrm{hr} \\
\left(\mathrm{x} 10^{16}\right)\end{array}$ & $\begin{array}{l}\text { Peak } \\
\text { Hour } \\
\text { Average } \\
(\mathrm{ppm})\end{array}$ & $\begin{array}{l}\text { Inhaled } \\
\text { Molecules } \\
\text { per peak hr } \\
\left(\mathrm{x} \mathrm{10} 0^{16}\right)\end{array}$ & $\begin{array}{l}\text { Maximum } \\
\text { Reading } \\
(\mathrm{ppm})\end{array}$ & $\begin{array}{l}\text { Minimum } \\
\text { Reading } \\
(\mathrm{ppm})\end{array}$ \\
\hline March & 2.07 & 4.14 & 2.70 & 5.40 & 11.68 & 0.00 \\
April & 1.87 & 3.74 & 2.25 & 4.50 & 13.26 & 0.18 \\
May & 2.62 & 5.24 & 3.75 & 7.50 & 14.91 & 0.23 \\
June & 2.85 & 5.70 & 3.75 & 7.50 & 17.60 & 0.00 \\
July & 0.94 & 1.88 & 1.35 & 2.70 & 12.01 & 0.18 \\
August & 0.75 & 1.50 & 1.13 & 2.26 & 9.22 & 0.15 \\
September & 2.93 & 5.86 & 3.83 & 7.66 & 19.10 & 0.21 \\
October & 2.41 & 4.82 & 3.00 & 6.00 & 13.56 & 0.12 \\
November & 2.40 & 4.80 & 3.08 & 6.16 & 18.46 & 0.56 \\
December & 1.76 & 3.52 & 2.10 & 4.20 & 13.41 & 0.46 \\
January & 2.01 & 4.02 & 2.78 & 5.56 & 19.04 & 0.08 \\
February & 1.49 & 2.98 & 2.10 & 4.20 & 13.00 & 0.21 \\
\hline
\end{tabular}


Table 2. Monthly means for concentrations and inhaled molecules of $\mathrm{NO}_{2}$ along with maximum and minimum readings

\begin{tabular}{lllll}
\hline Month & $24 \mathrm{hr}$ Average $(\mathrm{ppm})$ & $\begin{array}{l}\text { Inhaled Molecules } \\
\text { per } 24 \mathrm{hr}(\mathrm{x} \mathrm{10})\end{array}$ & $\begin{array}{l}\text { Maximum } \\
\text { Reading }(\mathrm{ppm})\end{array}$ & $\begin{array}{l}\text { Minimum } \\
\text { Reading }(\mathrm{ppm})\end{array}$ \\
\hline March & 0.050 & 1 & 0.349 & 0.001 \\
April & 0.048 & 0.96 & 0.431 & 0.002 \\
May & 0.063 & 1.3 & 0.417 & 0.000 \\
June & 0.057 & 1.1 & 0.405 & 0.002 \\
July & 0.023 & 0.46 & 0.335 & 0.004 \\
August & 0.020 & 0.4 & 0.322 & 0.000 \\
September & 0.062 & 1.2 & 0.458 & 0.002 \\
October & 0.050 & 1 & 0.397 & 0.004 \\
November & 0.053 & 1.1 & 0.432 & 0.006 \\
December & 0.044 & 0.88 & 0.348 & 0.005 \\
January & 0.051 & 1.02 & 0.415 & 0.002 \\
February & 0.034 & 0.68 & 0.413 & 0.001 \\
\hline
\end{tabular}

Table 3. Monthly means for concentrations and inhaled molecules of $\mathrm{SO}_{2}$ along with maximum and minimum readings

\begin{tabular}{lllll}
\hline Month & $24 \mathrm{hr}$ Average (ppm) & $\begin{array}{l}\text { Inhaled Molecules } \\
\text { per } 24 \mathrm{hr}\left(\mathrm{x} \mathrm{10} 0^{13}\right)\end{array}$ & $\begin{array}{l}\text { Maximum } \\
\text { Reading }(\mathrm{ppm})\end{array}$ & $\begin{array}{l}\text { Minimum } \\
\text { Reading (ppm) }\end{array}$ \\
\hline March & 0.003 & 6.00 & 0.007 & 0.00 \\
April & 0.003 & 6.00 & 0.006 & 0.00 \\
May & 0.004 & 8.00 & 0.011 & 0.00 \\
June & 0.004 & 8.00 & 0.008 & 0.00 \\
July & 0.002 & 4.00 & 0.007 & 0.00 \\
August & 0.001 & 2.00 & 0.006 & 0.00 \\
September & 0.004 & 8.00 & 0.009 & 0.00 \\
October & 0.003 & 6.00 & 0.010 & 0.00 \\
November & 0.005 & 10.0 & 0.013 & 0.00 \\
December & 0.003 & 6.00 & 0.008 & 0.00 \\
January & 0.003 & 6.00 & 0.006 & 0.00 \\
February & 0.002 & 4.00 & 0.009 & 0.00 \\
\hline
\end{tabular}

The CO recorded levels ranged from 0.00 to $19.20 \mathrm{ppm}$ during this monitoring period. The annual mean concentration of $\mathrm{CO}$ based on the maximum 8 hour average was $2.01 \mathrm{ppm}$. This annual value is lower than both the NAASQ $(9.00 \mathrm{ppm})$ and the 2007 US EPA reported $\mathrm{O}_{3}$ average $(2.04 \mathrm{ppm})$ which is based on 229 monitoring sites. However, as seen in Table 1, the CO monthly concentrations exceeded the 2007 US EPA reported CO average six times during the year but were always lower than the current 8-hour CO NAAQS value. With $\mathrm{NO}_{2}$, the annual mean concentration was $0.046 \mathrm{ppm}$. This mean is close to the NAAQS of $0.053 \mathrm{ppm}$ (annual average) but is well over the recorded annual average of $0.013 \mathrm{ppm}$ which is based on 160 monitoring sites across different cities in the USA. The lowest $\mathrm{NO}_{2}$ monthly means were calculated during the months of July ( 0.023 ppm) and August (0.020 ppm). All $\mathrm{NO}_{2}$ monthly averages exceeded the 2007 US EPA reported $\mathrm{NO}_{2}$ average. The annual mean concentration for $\mathrm{SO}_{2}$ was calculated at $0.003 \mathrm{ppm}$ which is significantly lower than the NAAQS of 0.03 ppm but relatively close to the 2007 US EPA reported $\mathrm{SO}_{2}$ average of $0.004 \mathrm{ppm}$ (based on 281 
monitoring sites). It can be seen that the annual mean for NMHC was $0.700 \mathrm{ppm}$ which is significantly higher than the NAAQS set at $0.240 \mathrm{ppm}$ carbon by volume (ppmC). Finally, the $\mathrm{O}_{3}$ recorded levels ranged from 0.006 to 0.108 ppm during this monitoring period. The annual mean concentration of $\mathrm{O}_{3}$ based on the maximum 8 hour average was $0.049 \mathrm{ppm}$. This annual value is lower than both the NAASQ $(0.080 \mathrm{ppm})$ and the 2007 US EPA reported $\mathrm{O}_{3}$ average $(0.077 \mathrm{ppm})$ which is based on 568 monitoring sites. However, as seen in Table 5, summer $\mathrm{O}_{3}$ concentrations (July $0.072 \mathrm{ppm}$ and August $0.069 \mathrm{ppm}$ ) almost reached both the current 8-hour $\mathrm{O}_{3} \mathrm{NAAQS}$ and the 2007 US EPA reported $\mathrm{O}_{3}$ average.

Airborne pollutants that are inhaled might either affect pulmonary or extrapulmonary organs (Watson et al., 1988). Consequently, the average number of $\mathrm{CO}, \mathrm{NO}_{2}, \mathrm{SO}_{2}$, and $\mathrm{O}_{3}$ molecules (theoretical calculation based on monthly averages and monthly peak hour average in case of $\mathrm{CO}$ and $\mathrm{O}_{3}$ ) inhaled per breath are included in Tables 1, 2, 3, and 5, respectively (Eubanks et al., 2009) in order to speculate on their health effects.

Table 4. Monthly means form concentrations of NMHC along with maximum and minimum readings

\begin{tabular}{llll}
\hline Month & 24 hr Average $(\mathrm{ppm})$ & Maximum Reading $(\mathrm{ppm})$ & $\begin{array}{l}\text { Minimum } \\
(\mathrm{ppm})\end{array}$ \\
\hline March & 0.70 & 3.60 & 0.01 \\
April & 0.69 & 5.71 & 0.05 \\
May & 0.83 & 3.37 & 0.04 \\
June & 0.82 & 8.05 & 0.04 \\
July & 0.31 & 4.42 & 0.05 \\
August & 0.22 & 4.43 & 0.05 \\
September & 0.99 & 9.17 & 0.08 \\
October & 0.83 & 5.81 & 0.07 \\
November & 0.90 & 8.35 & 0.08 \\
December & 0.75 & 5.66 & 0.09 \\
January & 0.75 & 8.00 & 0.01 \\
February & 0.55 & 8.85 & 0.00 \\
\hline
\end{tabular}

Table 5. Monthly means for concentrations, peak hour concentrations, and inhaled molecules of $\mathrm{O}_{3}$ along with maximum and minimum readings

\begin{tabular}{lllllll}
\hline Month & $\begin{array}{l}\text { Maximum } \\
8 \mathrm{hr} \\
\text { Average } \\
(\mathrm{ppm})\end{array}$ & $\begin{array}{l}\text { Inhaled } \\
\text { Molecules } \\
\text { per } 8 \mathrm{hr} \\
\left(\times 10^{15}\right)\end{array}$ & $\begin{array}{l}\text { Peak Hour } \\
\text { Average } \\
(\mathrm{ppm})\end{array}$ & $\begin{array}{l}\text { Inhaled } \\
\text { Molecules } \\
\text { per peak hr } \\
\left(\mathrm{x} \mathrm{10} 0^{15}\right)\end{array}$ & $\begin{array}{l}\text { Maximum } \\
\text { Reading } \\
(\mathrm{ppm})\end{array}$ & $\begin{array}{l}\text { Minimum } \\
\text { Reading } \\
(\mathrm{ppm})\end{array}$ \\
\hline March & 0.059 & 1.18 & 0.068 & 1.36 & 0.079 & 0.014 \\
April & 0.06 & 1.2 & 0.079 & 1.58 & 0.095 & 0.012 \\
May & 0.052 & 1.04 & 0.061 & 1.22 & 0.074 & 0.019 \\
June & 0.048 & 0.96 & 0.060 & 1.2 & 0.072 & 0.017 \\
July & 0.072 & 1.44 & 0.091 & 1.82 & 0.108 & 0.019 \\
August & 0.069 & 1.38 & 0.087 & 1.74 & 0.104 & 0.018 \\
September & 0.054 & 1.08 & 0.063 & 1.26 & 0.089 & 0.016 \\
October & 0.052 & 1.04 & 0.063 & 1.26 & 0.077 & 0.013 \\
November & 0.032 & 0.64 & 0.049 & 0.98 & 0.059 & 0.009 \\
December & 0.027 & 0.54 & 0.041 & 0.82 & 0.059 & 0.008 \\
January & 0.029 & 0.58 & 0.031 & 0.62 & 0.041 & 0.011 \\
February & 0.037 & 0.74 & 0.043 & 0.86 & 0.050 & 0.006 \\
\hline
\end{tabular}


Once inhaled, $\mathrm{CO}$ forms a strong bond with hemoglobin producing carboxyhemoglobin $(\mathrm{COHb})$. Thus, putting a strain on tissue with high oxygen demand, such as the heart and the brain since it impairs the oxygen carrying capacity of the blood (Malakootian \& Yaghmaeian, 2004). A person can experience subtle cardiovascular, respiratory, and neurobehavioral effects when exposed to low concentrations of $\mathrm{CO}$ around $10 \mathrm{ppm}\left(20 \times 10^{17}\right.$ inhaled molecules). Unconsciousness or even death can occur after prolonged or acute exposures to concentrations of $\mathrm{CO}$ higher than $500 \mathrm{ppm}$ (greater than $1 \times 10^{19}$ inhaled molecules) (Varon, Marik, Fromm, \& Gueler, 1999). By looking at Table 1, it can be clearly stated that all the calculated average inhaled CO molecules are within safe limits; however, these numbers correspond to the ambient $\mathrm{CO}$ concentrations and not to the high short-term concentrations (around $50 \mathrm{ppm}-1 \times 10^{18}$ inhaled molecules) that can be experienced by commuters and pedestrians during peak traffic hours when highways are congested by motor vehicles. These high short-term $\mathrm{CO}$ concentrations can cause health effects in the general population and in high risk group such as young children, the elderly, and people with heart or respiratory problems. Inhalation of $\mathrm{NO}_{2}$ causes severe irritation of the innermost parts of the lungs resulting in pulmonary edema and fatal bronchiolitis fibrosa obliterans. Inhalation for even very brief periods of time of air containing 200-700 ppm of $\mathrm{NO}_{2}\left(4-14 \times 10^{18}\right.$ inhaled molecules) can be fatal. Concentration higher than 60-150 ppm (1.2 - 3 x $10^{18}$ inhaled molecules) can cause cough and burning sensation deep inside the lungs. Lungs damage can be visible after 2 to 24 hours. Continuous exposition to low concentration of $\mathrm{NO}_{2}$ can cause cough, headache, loss of appetite, and stomach problems (Ackermann-Liebuch \& Rapp, 1999; Brunekreef, Dockery, \& Krzyzanowski, 1995). Environmental studies had proven that children that had to sustain a continuous exposition to $\mathrm{NO}_{2}$ end up with an increasing of breathing disease and reduces breathing efficiency. By looking at Table 2, none of the calculated average inhaled $\mathrm{NO}_{2}$ molecules are close to the numbers reported above; however, continuous exposure of the Salmiyah residents to high $\mathrm{NO}_{2}$ levels might cause a respiratory health risk in the long run.

Table 6. Atmospheric standards of pollutants levels along with observed annual averages of these pollutants

\begin{tabular}{cccccc}
\hline Air Pollutant & Average(ppm) & Maximum(ppm) & Minimum(ppm) & $\begin{array}{c}\text { US EPA National } \\
\text { Ambient } \\
\text { Air Quality Standard } \\
(\mathrm{ppm})\end{array}$ & $\begin{array}{c}\text { 2007 US EPA } \\
\text { Reported } \\
\text { Average } \\
(\mathrm{ppm})\end{array}$ \\
\hline $\mathrm{CO}$ & 2.01 & 19.20 & 0.00 & 9.00 & 2.04 \\
$\mathrm{NO}_{2}$ & 0.046 & 0.458 & 0.001 & 0.053 & 0.013 \\
$\mathrm{SO}_{2}$ & 0.003 & 0.013 & 0.000 & 0.03 & 0.004 \\
$\mathrm{O}_{3}$ & 0.049 & 0.108 & 0.006 & 0.080 & 0.077 \\
$\mathrm{NMHC}$ & 0.70 & 9.17 & 0.01 & 0.240 & -- \\
\hline
\end{tabular}

$\mathrm{SO}_{2}$ enters the bloodstream through the lungs. Once in the body, it breaks down to sulfate and leaves through the urine. Health effects caused by exposure to high levels of $\mathrm{SO}_{2}$ include breathing problems, respiratory illness, changes in the lung's defenses, and worsening of existing respiratory and cardiovascular diseases (Walters, Griffiths, \& Ayres, 1994). Individuals suffering from asthma, chronic lung disease, or chronic heart disease are the most sensitive to ambient $\mathrm{SO}_{2}$ levels exceeding $2000 \mathrm{ppb}$ (greater than $4 \times 10^{16}$ inhaled molecules). Concentrations of $\mathrm{SO}_{2}$ ranging from 0 to $80 \mathrm{ppb}\left(0\right.$ to $1.6 \times 10^{15}$ inhaled molecules $)$ are expected to be safe since no health effects are expected to be experienced by healthy people (Linn, Avol, Penc, Shamoo, \& Hackney, 1987). The calculated average inhaled $\mathrm{SO}_{2}$ molecules expressed in Table 3 are considerably lower than the ones computed above. As a general rule, exposures to individual NMHC species are relatively low and health risks on a community-wide basis are considered to be small to negligible. NMHC such as aldehydes and acrolein are potent irritants. Exposure to these substances, individually or collectively, may cause eye, nose, throat, and sinus irritation. Such symptoms are transitory, resulting in no apparent long-term adverse health effects. The NAAQS for NMHC was established to serve only as a guide in assessing hydrocarbon emissions reductions needed to achieve $\mathrm{O}_{3}$ standards and was not designed to protect public health from exposure risks that may be associated with specific NMHC (Godish, 2004). Consequently, calculating the number of inhaled NMHC molecules would have been meaningless.

$\mathrm{O}_{3}$, a deep lung irritant, causes bronchial hyper-responsiveness following 7-hour exposures to $0.08,0.1$ or 0.12 ppm (1.6 × $10^{15}$ inhaled molecules, $2.0 \times 10^{15}$ inhaled molecules, or $2.4 \times 10^{15}$ inhaled molecules), or a 1-hour 
exposure to $0.35 \mathrm{ppm}\left(7 \times 10^{15}\right.$ inhaled molecules) (Manahan, 1992). This response occurs almost immediately following exposure to $\mathrm{O}_{3}$ and persists for at least 18 hours. Other symptoms observed following acute exposures to $0.25-0.75 \mathrm{ppm}\left(0.5-1.5 \times 10^{16}\right.$ inhaled molecules) include cough, shortness of breath, tightness of the chest, a feeling of an inability to breathe (dyspnea), dry throat, wheezing, headache and nausea. More severe symptoms have been seen following exposure to higher concentrations (greater than $1 \mathrm{ppm}$; greater than $2 \times 10^{16}$ inhaled molecules) and have included reduced lung function, extreme fatigue, dizziness, inability to sleep and to concentrate and a bluish discoloration of the skin (cyanosis). Intermittent exposure to $9 \mathrm{ppm}\left(1.8 \times 10^{17}\right.$ inhaled molecules) for 3-14 days has produced inflammation of the bronchi and lungs. An acute occupational exposure to approximately $11 \mathrm{ppm}\left(2.2 \times 10^{17}\right.$ inhaled molecules $)$ for 15 minutes caused severe respiratory irritation and almost caused unconsciousness. 30-minute exposure to $50 \mathrm{ppm}\left(1 \times 10^{18}\right.$ inhaled molecules $)$ is considered potentially lethal. $\mathrm{O}_{3}$ concentrations, greater than $2 \mathrm{ppm}$, can be irritating to the eyes within minutes. No definite effects on vision were noted in volunteers exposed for 3 or 6 hours to 0.2-0.5 ppm (Devlin, Raub, \& Folinsbee, 1997; Horstman, Folinsbee, Ives, Abdul-Salaam, \& McDonnell, 1990). By looking at Table 5, it is clear that during the months of July and August the average number of inhaled $\mathrm{O}_{3}$ molecules per 8 hours $\left(1.44 \times 10^{15}\right.$ and $1.38 \times 10^{15}$ compared to $1.6 \times 10^{15}$ molecules) might cause a specific sector of the human population in Salmiyah (pedestrians and individuals working daily shifts outside such as construction and utility workers) to experience bronchial hyper-responsiveness; however, the levels of inhaled $\mathrm{O}_{3}$ molecules are safe for the remainder of the year.

In a recent study (Al-Khalaf; Al-Khulaifi; Al-Taher; Al-Saleh, \& Abdul Reza, 2010), a survey was conducted in order to evaluate the impact of air pollution on human health in different areas of Kuwait from March to June 2005. 925 subjects participated in this survey out of which 325 were residents of Salmiyah. The results of the surveys taken by Salmiyah residents revealed the following existing health conditions; 25\% (82/325) had respiratory diseases, $15.4 \%(50 / 325)$ had allergies and $8.3 \%(27 / 325)$ had asthma. In addition, the highest prevalence of existing diseases was observed in the residents of Salmiyah; $35.3 \%(82 / 232)$ had respiratory diseases, $42.3 \%(50 / 118)$ had allergies and $27.5 \%$ (27/98) had asthma. The paper concluded that there is a possible link between the reported health conditions and road emissions. No road emissions data was cited in the survey; however, our current data shows that the emissions of gaseous air pollutants are high in Salmiyah and can be undoubtedly and clearly associated with the health conditions reported by the residents. Both the conclusion reached in the survey and our assumption are confirmed by a numerous number of research publications, spanning over three decades, indicating clearly that elevated levels of air pollutants (both gaseous and particulate) are associated with adverse human respiratory effects (Wilson, 2009; Stieb, Szysszkowics, Rowe, \& Leech, 2009; Jerrett et al., 2009; Thurston \& Bates, 2003; Bates, 1995; Walters et al., 1994; Dockery et al., 1993).

\subsection{Diurnal Variations}
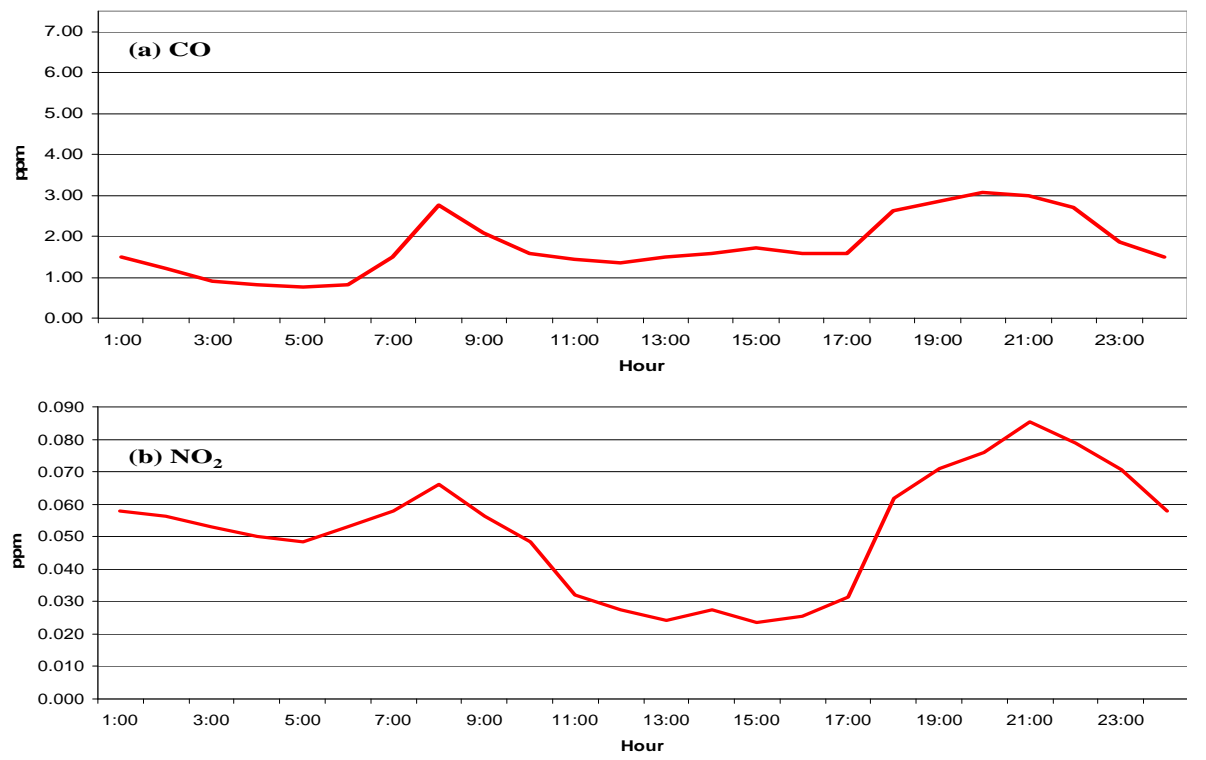

Figure 2(a, b). Diurnal variations of (a) $\mathrm{CO}$ and (b) $\mathrm{NO}_{2}$ during the month of November 2008 in the Salmiyah residential area 
Traffic density is known to vary during different day times. In order to better study the variations in $\mathrm{CO}, \mathrm{NO}_{2}$, $\mathrm{SO}_{2}$, NMHC, and $\mathrm{O}_{3}$ concentrations in the Salmiyah residential area, their concentrations were analyzed by computing their monthly average values at the top of the hour during a twenty-four hour period. A representative plot for each of the diurnal variations in $\mathrm{CO}, \mathrm{NO}_{2}, \mathrm{SO}_{2}, \mathrm{NMHC}$, and $\mathrm{O}_{3}$ concentrations during the month of November 2008 is shown in Figure 2. Before discussing our findings, it is worth noting that in Kuwait, traffic is considered of major significance to the urban pollution load. The current estimated number of registered vehicles in Kuwait stands at 1.5 million. In automobile exhausts, $\mathrm{CO}$ and other incomplete combustion products are released along with $\mathrm{NO}_{\mathrm{x}}$. As mentioned earlier, both $\mathrm{NO}_{2}$ (product of $\mathrm{NO}_{\mathrm{x}}$ ) and organic compounds resulting form incomplete combustion are key to formation of $\mathrm{O}_{3}$. Catalytic converters decrease the $\mathrm{O}_{3}$ formation rate by oxidizing the incomplete combustion products to $\mathrm{CO}_{2}$ and by reducing $\mathrm{NO}_{\mathrm{x}}$ to $\mathrm{N}_{2}$ and $\mathrm{O}_{2}$. Catalytic converters have been helpful in controlling $\mathrm{O}_{3}$ pollution in countries where they are used (Bradley \& Jones, 2002; Courty \& Chauvel, 1996). However, Kuwait does not enforce the use of catalytic converters in cars. A twenty year old report estimated that road transport is the source of $95.9 \%$ of $\mathrm{CO}, 76.2 \%$ of hydrocarbons, and $25.9 \%$ of $\mathrm{NO}_{\mathrm{x}}$ in Kuwait City (Al-Damkhi \& Boushari, 1986). In addition, gasoline in Kuwait has a sulfur content of 400-450 ppm which is significantly higher than the U. S. gasoline sulfur content of $80-95 \mathrm{ppm}$ (United Nations Environmental Programme, 2005).

In Kuwait, traffic movement is characterized by three distinct peaks. The first is characterized by the morning commute to work (7:00-8:00 hours), the second is the early afternoon peak associated with commuting back from work (14:00-15:00 hours), and the third and longest peak, extending from 19:00 till 22:00, results from the nightly work shift and both shopping and leisure trips. Figure 2 shows two types of concentration variations exhibited by the pollutants. The hourly mean distribution of $\mathrm{CO}, \mathrm{NO}_{2}, \mathrm{SO}_{2}$, and $\mathrm{NMHC}$, primary pollutants, were characterized by three peaks; on the other hand, the variation corresponding to $\mathrm{O}_{3}$, a secondary pollutant, revealed the occurrence of two daily maxima.

The diurnal peaks of $\mathrm{CO}, \mathrm{NO}_{2}, \mathrm{SO}_{2}$, and NMHC (Figures. 2a, 2b, 2c, and 2d) over a 24 hour period occurred around 7:00-8:00 hours (morning peak), 13:00-14:00 hours (afternoon peak), and 19:00-22:00 hours peak (evening peak). The morning peak was shorter whereas the second peak was much lower and less marked. During the late morning and afternoon, expansion of the boundary layer and the concomitant entertainment of relatively clean air from above as well as a decrease in traffic can cause these concentrations to decrease substantially. This is probably the reason why the afternoon peak was shallow and less marked. The evening peak was much longer and was significantly more marked all year round. This is significantly reflected in the case of $\mathrm{SO}_{2}$ where the ambient concentrations are higher due to traffic congested highways that include heavy diesel (sulfur content $1000 \mathrm{ppm}$ ) (UNEP, 2005) operated vehicles such as trucks and mass transit buses etc. in addition to passenger vehicles. It can be certainly concluded that the $\mathrm{CO}, \mathrm{NO}_{2}, \mathrm{SO}_{2}$, and $\mathrm{NMHC}$ three peaks overlapped with the heavy traffic loads during rush hours in the Salmiyah residential area. Previous studies (Abdul-Wahab \& Bouhamra 2004; El Dessouky \& Abdulraheem 1987) conducted in Kuwait were divided in their conclusions since some researchers confirmed the observation of the 3 peaks mentioned above while others only observed two peaks occurring in the morning and at night, respectively; however, all studies were unanimous in associating these peaks with heavy traffic hours.

The diurnal variation of $\mathrm{O}_{3}$ is shown in Figure. 2e. The shape of the $\mathrm{O}_{3}$ curve shows two peaks in a twenty four hour period and is completely opposite in pattern to those of $\mathrm{CO}, \mathrm{NO}_{2}, \mathrm{SO}_{2}$, and $\mathrm{NMHC}$. The first peak was slight and was observed at 4:00-5:00 hours while the second peak was more significant and extended for a longer time period spanning a 11:00 to 17:00 time window. Low concentrations of $\mathrm{O}_{3}$ were observed at 7:00 and between 19:00 to 1:00. This fluctuation, with high $\mathrm{O}_{3}$ concentrations during midday compared to the morning, late evening, and night hours, was explained by the fluctuation in the $\mathrm{O}_{3}$ precursors' emission $\left(\mathrm{NO}_{\mathrm{x}}\right.$ and $\left.\mathrm{NMHC}\right)$, light intensity, and atmospheric dilution processes. This behavior was believed to reflect photochemical production and downward transport of $\mathrm{O}_{3}$ rich air from above during the daylight hours and ozone loss by dry deposition and reaction with $\mathrm{NO}$ to produce $\mathrm{NO}_{2}$ during the night hours when photochemical production stopped and vertical transport was inhibited by a nocturnal inversion.

A number of previous $\mathrm{O}_{3}$ studies conducted both in Kuwait and around the world confirmed the existence of the second (afternoon) peak (Bouhamra \& Abdul Wahab, 1999; Abdul-Wahab \& Bouhamra, 2004; Varshney \& Aggarwal, 1992; Lorenzini, Nali, \& Panicucci, 1992); in addition, recent studies reported the observation of the first (nocturnal) $\mathrm{O}_{3}$ peak (Bouhamra \& Abdul Wahab, 1999; Abdul-Wahab \& Bouhamra, 2004; Eliasson, Thorsson, \& Andersson-Skold, 2003; Alp \& Asude-Ozkan, 2009). 

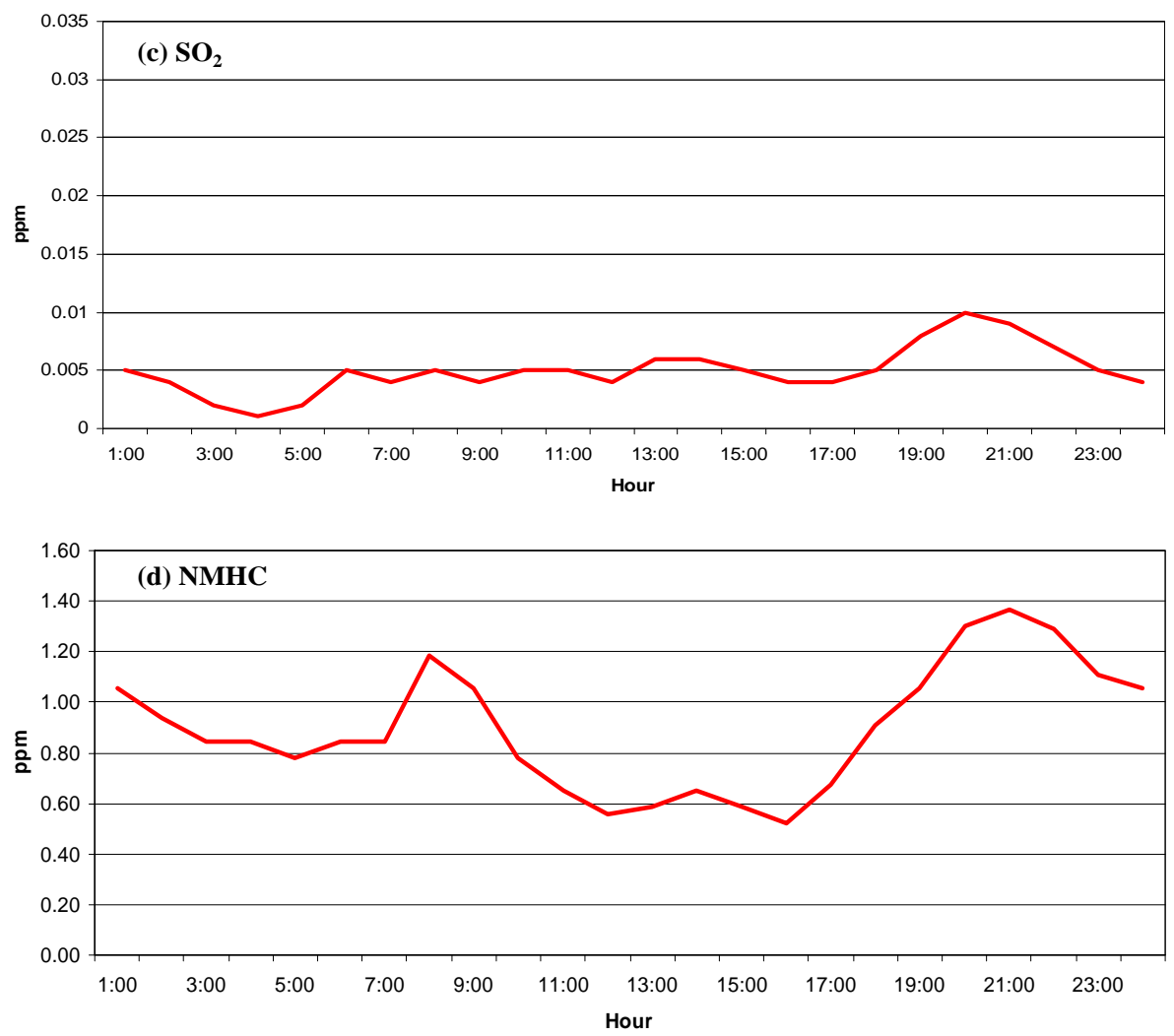

Figure 2(c, d). Diurnal variations of (c) $\mathrm{SO}_{2}$ and (d) NMHC during the month of November 2008 in the Salmiyah residential area

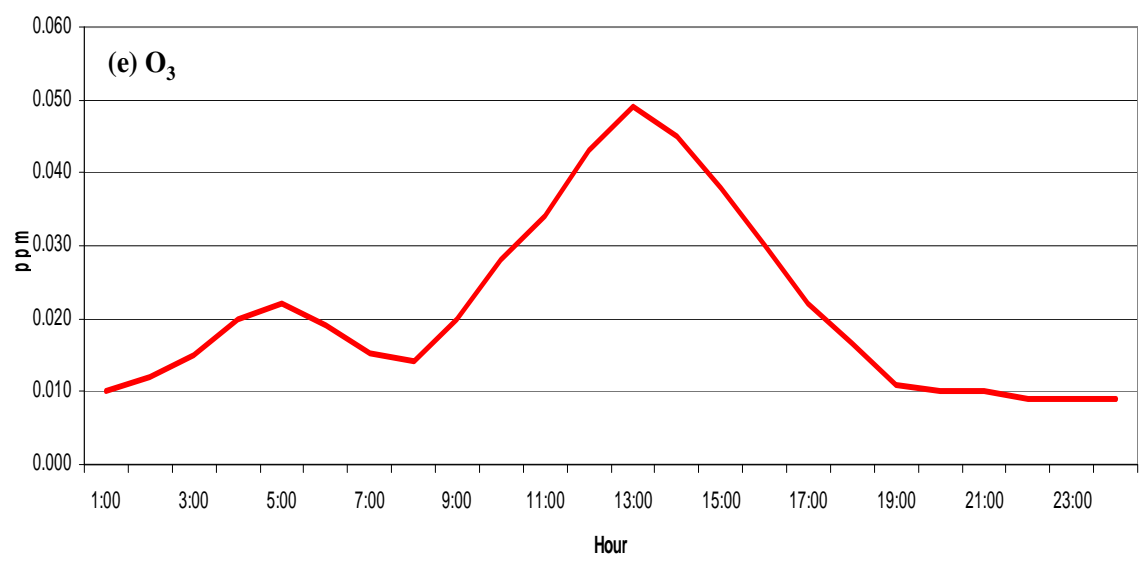

Figure 2(e). Diurnal variations of (e) $\mathrm{O}_{3}$ during the month of November 2008 in the Salmiyah residential area

These studies attributed the origin of the $\mathrm{O}_{3}$ afternoon peak to the photochemical reactions. The morning $\mathrm{O}_{3}$ precursors were observed to occur because of the morning rush hours (experienced worldwide). Because of the solar insulation during the daytime period, the photochemical $\mathrm{O}_{3}$ production rate started to increase until the $\mathrm{O}_{3}$ exhibited the afternoon peak. The evening rush hours did not produce a second $\mathrm{O}_{3}$ (late evening/night) peak due to the lack of sunlight late in the day. Researchers linked the nocturnal $\mathrm{O}_{3}$ peak to insufficient $\mathrm{NO}$ needed to remove the $\mathrm{O}_{3}$ that accumulated overnight in the surface atmospheric boundary layer (Samson, 1978; Liu, Liu, \& Shen, 1990). Besides, researchers at the Environmental Protection Department of the Ministry of Public Health in Kuwait indicated in a report more than 20 years old (El Dessouky \& Abdul-Wahab, 1988) that $\mathrm{O}_{3}$ begins to accumulate to reach a peak at 4:00 due to insufficient NO concentration to react with. This was justified by the 
surface-based inversion layer which occurred in Kuwait during the vast majority of the nights (98.4\%) and had an approximate mean duration of 12 hours per day. The intensity and strength of this layer was detected in the early morning hours coinciding with the $\mathrm{O}_{3}$ nocturnal peak.

\subsection{Seasonal Distributions}

Climate in Kuwait is typically arid with very hot summers and relatively cold winters. The summer season in Kuwait falls between May and September and the winter season between November and March. Summer temperatures do exceed $50^{\circ} \mathrm{C}$, and in January, the coldest month, temperatures range from $0^{\circ} \mathrm{C}$ (inland desert areas) to $20^{\circ} \mathrm{C}$ (coastal areas). The monthly mean distributions for both temperature and relative humidity along with the maximum recorded readings corresponding to the period extending from March 2008 until February 2009 are shown in Figures. 3a and 3b, respectively. The highest average temperature of $47^{\circ} \mathrm{C}$ was computed in August versus the lowest of $14.9^{\circ} \mathrm{C}$ in January. Regarding relative humidity, October had the highest mean of $48.9 \%$, while July observed the lowest of $23 \%$.

The monthly mean distributions for $\mathrm{CO}, \mathrm{NO}_{2}, \mathrm{SO}_{2}, \mathrm{NMHC}$, and $\mathrm{O}_{3}$ are shown in Figures. $4 \mathrm{a}$ to $4 \mathrm{e}$, respectively. It can be seen that the concentration means of $\mathrm{CO}, \mathrm{NO}_{2}, \mathrm{SO}_{2}$, and $\mathrm{NMHC}$ showed similar distinct monthly patterns, with the lower concentrations observed during the summer season (July and August), while the higher concentrations were experienced during the winter (January), late spring (May), and early fall (September) seasons. Previous studies have reported relatively higher CO concentrations during the winter months and linked such behavior to nocturnal inversions and seasonal variation in traffic modes (Akland, Hartwell, Johnson, \& Whitmore, 1985; North, Hernandez, \& Garcia, 1984). Literatures searches also revealed that winter $\mathrm{NO}_{\mathrm{x}}(\mathrm{NO}$ and $\mathrm{NO}_{2}$ ) concentration means are higher (almost 2-3 times) than those observed during the summer times (USEPA, 1978). Similar $\mathrm{SO}_{2}$ and $\mathrm{NMHC}$ seasonal trends were reported in previous studies (Crocker \& Applegate, 1983; Gray, Case, Huntzicker, Heyerdahl, \& Rau, 1986). In addition, it was previously reported that climatological factors and mixing height could play a major role in causing such $\mathrm{NO}_{2}$ and $\mathrm{NMHC}$ patterns (Abdul-Wahab \& Bouhamra, 2004). $\mathrm{O}_{3}$ exhibited an opposite trend compared to those of $\mathrm{CO}_{2} \mathrm{NO}_{2}, \mathrm{SO}_{2}$, and NMHC. High levels of $\mathrm{O}_{3}$ were detected during the summer season (July 0.072 ppm and August 0.069 ppm), while lower levels were distributed over the winter season (December 0.027 ppm and January 0.029 ppm). Numerous studies conducted around the world reported high $\mathrm{O}_{3}$ levels during the summer season (Bouhamra \& Abdul Wahab, 1999; Abdul-Wahab \& Bouhamra, 2004; Varshney \& Aggarwal, 1992; Lorenzini, Nali, \& Panicucci, 1992)). This common behavior of $\mathrm{O}_{3}$ was justified by the dominant photochemical production process of $\mathrm{O}_{3}$ due to the presence of $\mathrm{NO}_{\mathrm{x}}, \mathrm{NMHC}$, and intense solar insolation (observed summer temperatures-Figure 3a) during the summer times.
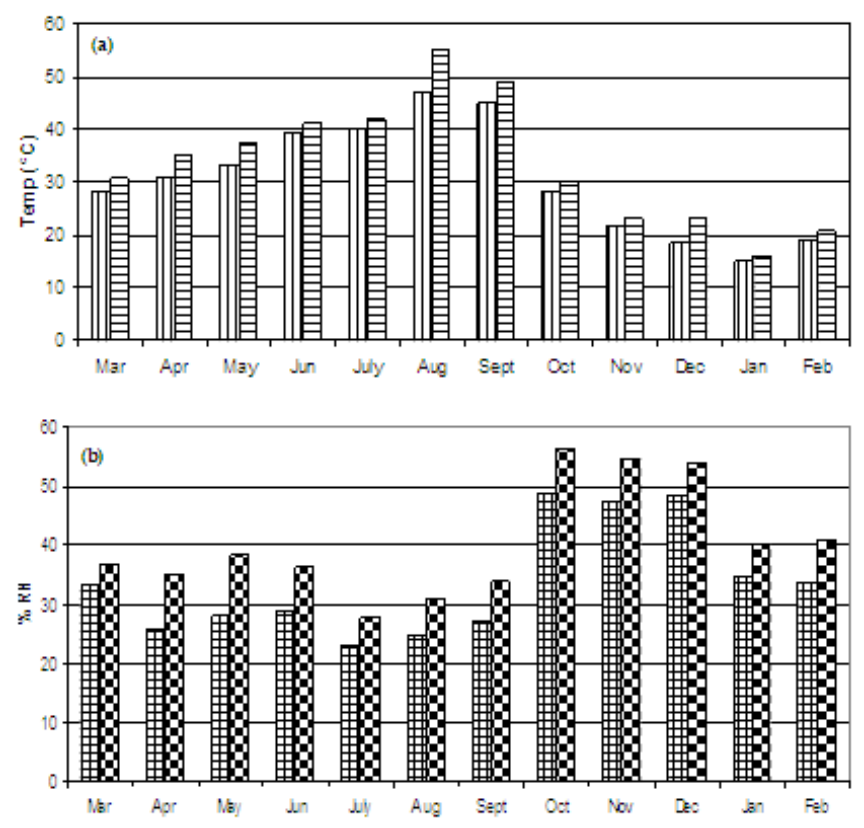

Figure 3(a, b). Monthly mean distributions of (a) temperature and (b) \% relative humidity along with the maximum recorded reading in the Salmiyah residential area 

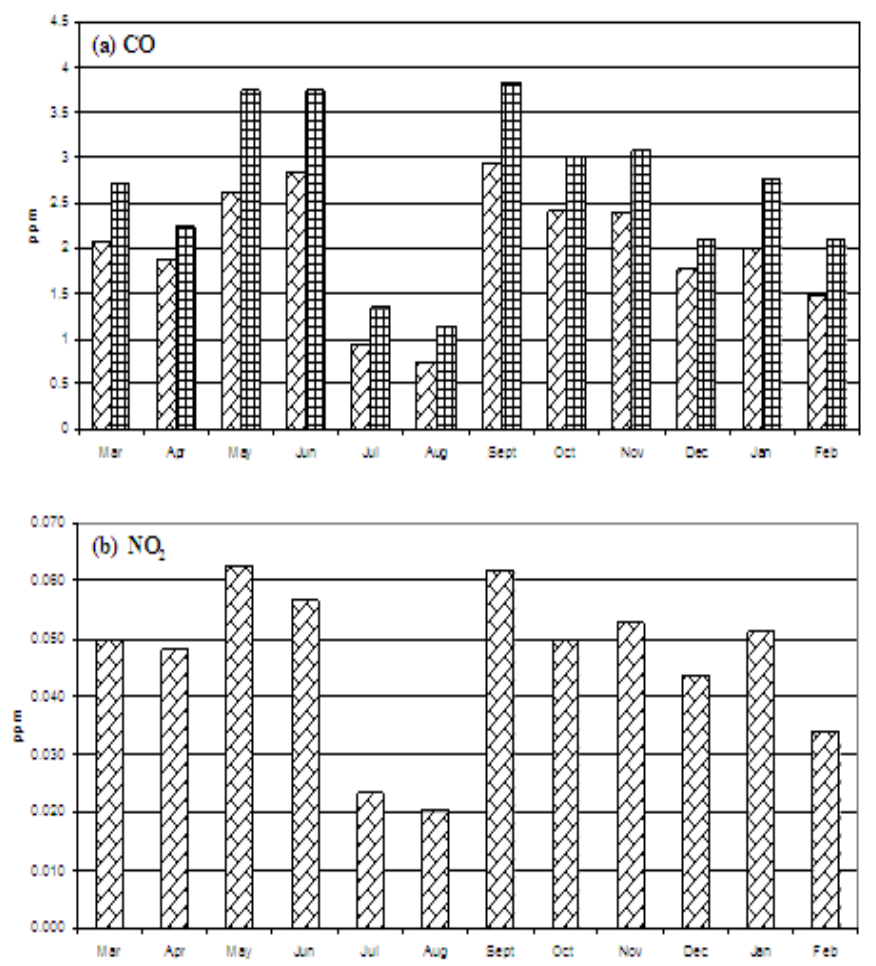

Figure 4(a, b). Monthly mean distribution of (a) $\mathrm{CO}$ and (b) $\mathrm{NO}_{2}$ in the Salmiyah residential area (In case of both $\mathrm{CO}$ and $\mathrm{O}_{3}$, monthly mean distribution of peak hour is also shown)
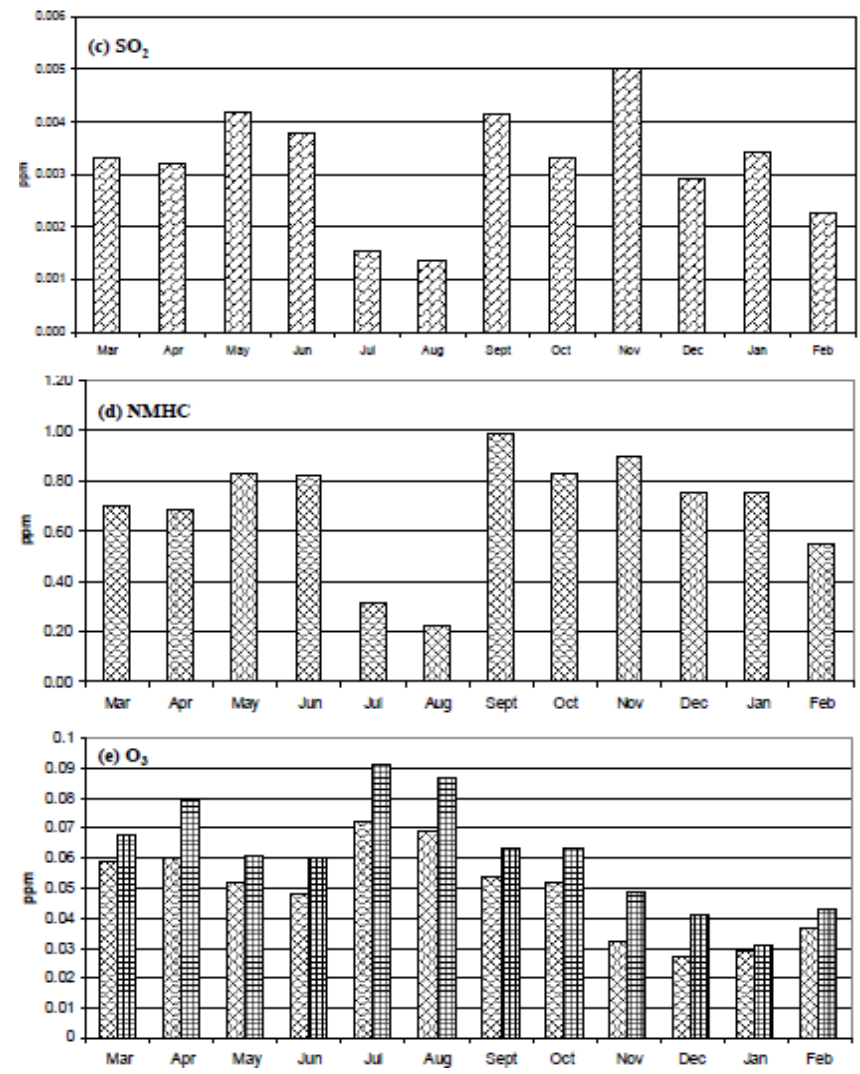

Figure 4(c, d, e). Monthly mean distribution of (c) $\mathrm{SO}_{2}$ (d) NMHC and (e) $\mathrm{O}_{3}$ in the Salmiyah residential area (In case of both $\mathrm{CO}$ and $\mathrm{O}_{3}$, monthly mean distribution of peak hour is also shown 
The low levels of $\mathrm{O}_{3}$ during the fall and winter seasons in the Salmiyah residential area could be explained as follows according to the existing literature (Atkinson, 2000). The presence of relatively low levels of $\mathrm{O}_{3}$ in the troposphere is important, because photolysis of $\mathrm{O}_{3}$ at wavelengths $\leq 335 \mathrm{~nm}$ (UV-C) occurs in the troposphere to form the excited oxygen $\mathrm{O}\left({ }^{1} \mathrm{D}\right)$ that can react with water vapor to generate hydroxyl $(\mathrm{OH})$ radicals at moderate temperatures $\left(25^{\circ} \mathrm{C}\right)$ and high relative humidity $(50 \%)$ which are similar to the meteorological conditions during the fall and winter seasons in Kuwait. The produced $\mathrm{OH}$ radical will destroy $\mathrm{O}_{3}$ to produce $\mathrm{NO}_{2}$ according to the following reactions;

$$
\begin{gathered}
\mathrm{O}_{3}+\mathrm{h} v \rightarrow \mathrm{O}_{2}+\mathrm{O}\left({ }^{1} \mathrm{D}\right) \quad(\lambda \leq 335 \mathrm{~nm}) \\
\mathrm{O}\left({ }^{1} \mathrm{D}\right)+\mathrm{H}_{2} \mathrm{O} \rightarrow 2 \mathrm{OH} \\
\mathrm{OH}+\mathrm{O}_{3} \rightarrow \mathrm{HO}_{2}+\mathrm{O}_{2} \\
\mathrm{HO}_{2}+\mathrm{O}_{3} \rightarrow \mathrm{OH}+2 \mathrm{O}_{2} \\
\mathrm{HO}_{2}+\mathrm{NO} \rightarrow \mathrm{OH}+\mathrm{NO}_{2}
\end{gathered}
$$

Both moderately observed temperatures (November $21.5^{\circ} \mathrm{C}$, December $18.6^{\circ} \mathrm{C}$, January $14.9^{\circ} \mathrm{C}$, and February $19.1^{\circ} \mathrm{C}$ ) and high observed relative humidities (November $47.6 \%$, December $48.7 \%$, January $34.7 \%$, and February 33.7\%) during the fall and winter seasons, could be playing a significant role in destroying $\mathrm{O}_{3}$ to produce $\mathrm{NO}_{2}$ leading to low $\mathrm{O}_{3}$ levels and high $\mathrm{NO}_{2}$ levels. Low levels of $\mathrm{CO}, \mathrm{NO}_{2}, \mathrm{SO}_{2}$, and $\mathrm{NMHC}$ during the summer season in Salmiyah could be explained, although still controversial in the literature, by the start of the summer vacation where a significant number of the Salmiyah residents leave Kuwait (for at least two months) leading to a lower traffic density and thus lower emissions of primary pollutants.

\section{Conclusion}

This paper analyzed ambient $\mathrm{CO}, \mathrm{NO}_{2}, \mathrm{SO}_{2}, \mathrm{NMHC}$, and $\mathrm{O}_{3}$ data collected in the Salmiyah residential area over a one year period. The main objective of the study was to monitor the tropospheric levels of these gaseous air pollutants to compare their values to US EPA standards. Particular attention was paid to speculate on their health effects and to examine both the diurnal variation and the seasonal distribution of these pollutants. It was found that the summer $\mathrm{O}_{3}$ concentrations almost reached the current 8-hour $\mathrm{O}_{3} \mathrm{NAAQS}$, while $\mathrm{CO}, \mathrm{NO}_{2} \mathrm{SO}_{2}$, and NMHC levels either exceeded or were within the ambient air quality standards. It can be safely predicted that serious health effects (respiratory diseases) will be reported by the Salmiyah residents resulting from exposure to such air pollutants, particularly to $\mathrm{O}_{3}$ and $\mathrm{NO}_{2}$ levels. It was reported that $\mathrm{CO}, \mathrm{NO}_{2} \mathrm{SO}_{2}$, and $\mathrm{NMHC}$ diurnal variations exhibited three maxima in a twenty four hour period, while $\mathrm{O}_{3}$ revealed the occurrence of two daily maxima. It was deduced that $\mathrm{CO}, \mathrm{NO}_{2} \mathrm{SO}_{2}$, and $\mathrm{NMHC}$ concentrations have similar seasonal distributions with summer minima and winter maxima, while $\mathrm{O}_{3}$ illustrated an opposite picture. Finally, this study recommends that vehicular emission regulations should be enforced. In Salmiyah, vehicles are the major emitters of air pollutants. It is unlikely that the traffic density will decrease in the coming years; however, if both the absence of vehicular emission regulations and the lack of enforcing the installation of catalytic converters remain the case, it is predicted that the pollutant levels will certainly rise in the future.

\section{References}

Abdul-Wahab, S. A., \& Bouhamra, W. S. (2004). Diurnal variations of air pollution from motor vehicles in residential area. International Journal of Environmental Studies, 61(1), 73-98. http://dx.doi.org/10.1080/0020723032000130034

Ackermann-Liebuch, U., \& Rapp, R. (1999). Epidemiological effects of oxides, especially $\mathrm{NO}_{2}$. Air Pollution and Health. San Diego: Academic Press Inc.

Akland, G. G., Hartwell, T. D., Johnson, T. R., \& Whitmore, R. W. (1985). Measuring human exposure to carbon monoxide in Washington, DC, and Denver, Colarado, during the winter of 1982-1983. Environmental Science \& Technology, 19, 911-918. http://dx.doi.org/10.1021/es00140a004

Al-Damkhi, A. M., \& Boushari, F. A. (1986). Report on rapid assessment of land based sources of pollution in the state of Kuwait. Kuwait: Ministry of Public Health, Environmental Protection Department .

Al-Khalaf, B., Al-Khulaifi, N., Al-Taher, I., Al-Saleh, K., \& Abdul Reza, J. (2010). Health status of leisure walkers in Kuwait. Alexandria Bulletin, 46(2), 149-156.

Alp, K., \& Asude Ozkan, H. (2009). Determination of transport processes of nocturnal ozone in Istanbul atmosphere. International Journal of Environmental Studies, 39(34), 213-222. http://dx.doi.org/10.1504/IJEP.2009.028686 
Al-Traiji, A. (2007). Prospective view of traffic problems in Kuwait. Kuwait: Ministry of Interior, Traffic Department.

Atkinson, R. (2000). Atmospheric chemistry of VOCs and $\mathrm{NO}_{\mathrm{x}}$. Atmospheric Environment, 34, 2063-2101. http://dx.doi.org/10.1016/S1352-2310(99)00460-4

Bates, D. V. (1995). The effects of air pollution in children. Environmental Health Perspectives, 103(6), 49-53. http://dx.doi.org/10.2307/3432345

Bouhamra, W. S., \& Abdul Wahab, S. A. (1999). Description of outdoor air quality in a typical residential area in Kuwait. Environmental Pollution, 105, 221-229. http://dx.doi.org/10.1016/S0269-7491(98)00221-8

Bradley, M. J., \& Jones, B. M. (2002). Reducing global NOx emissions: Developing advance energy and transportation technologies. Ambio: A journal of the Human Environment, 31(2), 141-149.

Brunekreef, B., Dockery, D. W., \& Krzyzanowski, M. (1995). Epidemiological studies on short term effects of low levels of major ambient air pollution components. Environmental Health Perspectives, 103(2), 3-13. http://dx.doi.org/10.1289/ehp.95103s23

Code of Federal Regulations. (2005). National primary and secondary ambient air quality standards (CFR 40 Part 50). Washington, D.C.: U.S. Government Printing Office.

Courty, P. R., \& Chauvel, A. (1996). Catalysis, the turntable for a clean future. Catalysis Today, 29(1-4), 3-15. http://dx.doi.org/10.1016/0920-5861(95)00253-7

Crocker, J. E., \& Applegate, H. G. (1983). Ozone concentration in El Paso, Texas. Journal of the Air Pollution Control Association, 33, 129-130. http://dx.doi.org/10.1080/00022470.1983.10465555

Devlin, R. B., Raub, J. A., \& Folinsbee, L. J. (1997). Health effects of ozone. Science \& Medicine, May/June, $8-17$.

Dockery, D. W., Pope, A., Xu, X., Spengler, J. D., James, H. W., Fay, M. E., Ferris, B. G., \& Frank E. S. (1993). An association between air pollution and mortality in six U.S. cities. The New England Journal of Medicine, 329(24), 1753-1759. http://dx.doi.org/10.1056/NEJM199312093292401

El Dessouky, M., \& Abdulraheem, M. Y. (1987). Pollution by exhaust gases in the residential areas in Kuwait. SAE Technical Paper, 87, 1075.

El Dessouky, M., \& Abdul-Wahab, S. A. (1988). Ground based thermal inversion in Kuwait. Kuwait: Ministry of Public Health, Environmental Protection Department.

Eliasson, I., Thorsson, S., \& Andersson-Skold, Y. (2003). Summer nocturnal ozone maxima in Göteborg, Sweden. Atmospheric Environment, 37(19), 2615-2627. http://dx.doi.org/10.1016/S1352-2310(03)00205-X

Eubanks, L. P., Middlecamp, C. H., Heltzel, C. E., \& Keller, S. W. (2009). Chemistry in context: Applying chemistry to society (6th ed.). New York: McGraw Hill Higher Education.

Godish, T. (2004). Air quality (4th ed.). Boca Raton: CRC Press Inc.

Gray, H. A., Case, G. R., Huntzicker, J. J., Heyerdahl, E. K., \& Rau, J. A. (1986). Characteristics of atmospheric organic and elemental carbon particle concentrations in Los Angeles. Environmental Science \& Technology, 18, 2049-2054. http://dx.doi.org/10.1021/es00148a006

Hoek, G., Brunekreef, B., Goldbohm, S., Fischer, P., \& Van den Brandt, P. A. (2002). Association between mortality and indicators of traffic-related air pollution in the Netherlands: a cohort study. Lancet, 360(9341), 1203-1209. http://dx.doi.org/10.1016/S0140-6736(02)11280-3

Horstman, D. H., Folinsbee, L. J., Ives, P. J., Abdul-Salaam, S., \& McDonnell, W. F. (1990). Ozone concentration and pulmonary response relationships for 6.6 hour- exposures with five hours of moderate exercise to $0.08,0.10,0.12 \mathrm{ppm}$. American Review of Respiratory Disease, 142, 1158-1163. http://dx.doi.org/10.1164/ajrccm/142.5.1158

Jerrett, M., Burnett, R. T., Pope, C. A., Ito, K., Thurston, G., Krewski, D., Shi, Y., Calle, E., \& Thun, M. (2009). Long-Term Ozone Exposure and Mortality. The New England Journal of Medicine, 360(11), 1085-1095. http://dx.doi.org/10.1056/NEJMoa0803894

Linn, W. S., Avol, E. L., Penc, R. C., Shamoo, S. A., \& Hackney, J. D. (1987). Replicated dose-response study of sulfur dioxide effects in normal, atopic and asthmatic volunteers. American Review of Respiratory Disease, 136, 1127-1134. http://dx.doi.org/10.1164/ajrccm/136.5.1127 
Liu, C., Liu, S., \& Shen, S. (1990). A study of Taipei ozone problem. Atmospheric Environment, 24A, 1461-1472. http://dx.doi.org/10.1016/0960-1686(90)90055-R

Lorenzini, G., Nali, C., \& Panicucci, A. (1992). Surface ozone in PISA (Italy): a six year study. Atmospheric Environment, 28(19), 3155-3164. http://dx.doi.org/10.1016/1352-2310(94)00151-A

Maheswaran, R. \& Elliot, P. (2003). Stroke mortality associated with living near main roads in England and Wales: a geographical study. Stroke, 34(12), 2776-2780. http://dx.doi.org/10.1161/ 01.STR.0000101750.77547.11

Malakootian, M. \& Yaghmaeian, K. (2004). Investigation of carbon monoxide in heavy traffic intersections of municipal districts. International Journal of Environmental Science \& Technology, 1(3), 227-231.

Manahan, S. E. (1992). Toxicological chemistry (2nd ed.). Chelsea: Lewis Publishers, Inc.

North, M., Hernandez, E., \& Garcia, R. (1984). Frequency analysis of CO concentrations in Madrid by stochastic process modeling. Atmospheric Environment, 18, 2049-2054. http://dx.doi.org/10.1016/0004-6981(84)90191-4

Samson, P. (1978). Nocturnal ozone maxima. Atmospheric Environment, 12, 951-955. http://dx.doi.org/10.1016/0004-6981(78)90035-5

Stieb, D. M., Szysszkowics, M., Rowe, B. H., \& Leech, J. A. (2009). Air pollution and emergency department visits for cardiac and respiratory conditions: a multi-city time-series analysis. Environmental Health, 8(25), 1-13. http://dx.doi.org/10.1186/1476-069X-8-25

Thurston, G. D., \& Bates, D. V. (2003). Air pollution as an underappreciated cause of asthma symptoms. The Journal of American Medical Association, 290, 1915-1917. http://dx.doi.org/10.1001/jama.290.14.1915

United States Environmental Protection Agency, Office of Research and Development. (1978). Air quality criteria for ozone and other photochemical oxidants. Michigan: University of Michigan Library.

United States Environmental Protection Agency. (2008). National air quality: Status and trends through 2007 (EPA Publication No. EPA 454/R-08-006). North Carolina, USA: Office of air quality and standards, air quality assessment division, research triangle park. Retrieved from http://www.epa.gov/airtrends/2008/report/TrendsReportfull.pdf

United Nations Environmental Programme. (2005). Global strategy for lower sulphur fuels of the partnership for clean fuels and vehicles. Nairobi, Kenya: Clearing-house for the partnership for clean fuels and vehicles. Retrieved from http://www.unep.org/transport/pcfv/PDF/PCFVSulphurStrategy-March08.pdf

Varon, J., Marik, P. E., Fromm, R. E. Jr, \& Gueler, A. (1999). Carbon monoxide poisoning: a review for clinicians. Journal of Emergency Medicine, 17(1), 87-93. http://dx.doi.org/10.1016/S0736-4679(98)00128-0

Varshney, C. K., \& Aggarwal, M. (1992). Ozone pollution in the urban atmosphere of Delhi. Atmospheric Environment, 26B(3), 291-294.

Walters, S., Griffiths, R., \& Ayres, K. (1994). Temporal association between hospital admissons for asthma in Birmingham and ambient levels of sulphur dioxide and smoke. Thorax, 49, 133-140. http://dx.doi.org/10.1136/thx.49.2.133

Watson, A. Y., Bates, R. D., \& Kennedy, D. (1988). Air pollution, the automobile, and public health. Washingon, D.C, National Academy Press.

Westerdahl, D., Wang, X., Pan, X., \& Zhang, K. M. (2009). Characterization of on-road vehicle emission factors and microenvironmental air quality in Beijing, China. Atmospheric Environment, 43, 697-705. http://dx.doi.org/10.1016/j.atmosenv.2008.09.042

Wilson, E. K. (2009). Ozone's health impact. Chemical \& Engineering News, 87(11), 9. http://dx.doi.org/10.1021/cen-v087n011.p009a 